\title{
I kriticky nemocný má právo na spojení s okolním světem
}

\author{
Jan Bělohlávek, Ilona Lálová, Vratislav Mrázek, Aleš Linhart \\ II. interní klinika kardiologie a angiologie, Všeobecná fakultní nemocnice a 1. lékařská fakulta Univerzity Karlovy, Praha, \\ Česká republika
}

Počítačové a informační systémy se staly v posledních letech nedílnou součástí nejen pracovního, ale i osobního života. Mobilní a komunikační technologie umožňují zůstat $\mathrm{v}$ kontaktu s okolním světem i v nejzávažnějších životních situacích, i v situacích, za kterých to bylo před pár lety nepředstavitelné. Kritické onemocnění není výjimkou; potřeba udržet si kontakt s príbuznými je u nemocných závislých na medikamentózní nebo př́strojové podpoře stejně důležitá, ne-li naléhavější než v běžném životě. Navíc každý má právo, aby byla zachována jeho lidská důstojnost, ${ }^{(1)}$ a k ní možnost komunikace s okolím patří. Komplex moderní intenzivní péče tak nemusí představovat jen dokonalé technické a personální vybavení, ale může zahrnout i snahu o zachování maximálního kontaktu kriticky nemocného pacienta se svými blízkými, a to jak osobní přítomností u lůžka, tak i formou vzájemné komunikace pomocí internetových aplikací.

\section{Literatura}

1. Zákon č. 2/1993 Sb. - Listina základních práv a svobod; Hlava druhá, článek 10, odst. 1.

2. Skype: http://en.wikipedia.org/wiki/skype

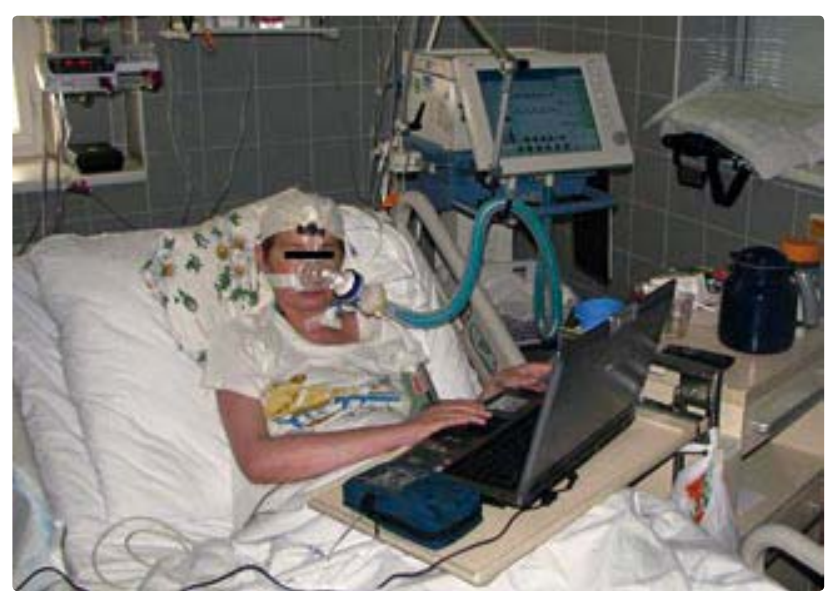

Na obrázku je nemocná pět týdnů zcela závislá na neinvazivní umělé plicní ventilaci a katecholaminové podpoře, která čeká na orgánovou transplantaci; díky laptopu $s \mathrm{Wi}-\mathrm{Fi}$ a připojením $\mathrm{k}$ internetu komunikuje prostřednictvím e-mailové pošty a video Skype ${ }^{(2)}$ se svou rodinou. Počítač byl pro tyto účely pořízen naším pracovištěm.

Adresa: MUDr. Jan Bělohlávek, II. interní klinika kardiologie a angiologie, VFN a 1. LF UK, U nemocnice 2, 12000 Praha 2, Česká republika, e-mail: Jan.Belohlavek@vfn.cz 